\title{
MEDIA PEMBELAJARAN ALA NABI (Kajian Living Hadis Riwayat Muslim Bab Birrun No. 149)
}

\author{
Arbain Nurdin \\ Dosen Institut Agama Islam Negeri (IAIN) Jember - Indonesia \\ Email: arbainnurdin86@gmail.com
}

\begin{abstract}
This article describes two research focuses namely how the value of instructional media in the Muslim history hadith chapter Birrun No. 149 and how to understand the meaning of the hadith and the practice of students as teachers of the practices of the Study Program of Hadith Science the Faculty of Usuluddin, Adab and Humanities of IAIN Jember. And the result is the value of learning media in the hadith is textually found in the word ashabi'u which means fingers. While students understand that the tradition of text has a textual discussion of how the task of parents to educate and take care of their daughters until they are adults, then practice students after understanding the meaning of the hadith contextually that is when becoming a teacher practice always and often use the media fingers in learning
\end{abstract}

\begin{abstract}
Abstrak
Artikel ini mendeskripsikan dua fokus penelitian yaitu bagaimana nilai media pembelajaran di dalam hadis riwayat Muslim bab birrun No. 149 dan bagaimana pemahaman makna hadis tersebut serta pengamalan mahasiswa selaku guru praktikan dari prodi Ilmu Hadis Fakultas Ushuluddin, Adab dan Humaniora IAIN Jember. Dan hasilnya adalah nilai media pembelajaran di dalam hadis tersebut secara tekstual ditemukan pada kata ashabi'u yang bermakna jari jemari. Sedangkan mahasiswa memahami bahwa matan hadis tersebut secara tekstual membahas tentang bagaimana tugas orang tua untuk mendidik dan menjaga anak-anak perempuannya hingga mereka dewasa, lalu pengamalan mahasiswa setelah memahami makna hadis tersebut secara kontekstual yaitu saat menjadi guru praktikan selalu dan sering menggunakan media jari jemari dalam pembelajaran.
\end{abstract}

Kata Kunci : Media Pembelajaran, Living Hadis 
JURNAL PIWULANG, Vol. 2 No. 2 Maret 2020, 99-111

P-ISSN : 2622-5638. E-ISSN : 2622-5654

Homepage: http://e-journal.staima-alhikam.ac.id/index.php/piwulang

\section{A. Pendahuluan}

Urgensi media dalam pembelajaran baik itu di lembaga formal seperti sekolah dan madrasah maupun di lembaga non formal seperti majelis-majelis taklim sudah terbukti, media juga memiliki peran yang sangat banyak bagi perkembangan kognitif peserta didik baik di tingkat dasar maupun menengah, ini berdasarkan beberapa hasil penelitian seperti penelitian yang dilakukan oleh Rafiuddin dkk. tentang urgensi media pembelajaran bagi guru Sekolah Dasar di kecamatan Sanrobone Takalar Sulawesi Selatan, penelitian ini menyimpulkan bahwa media sangat penting bagi guru dalam proses pembelajaran dan media tersebut bisa berupa media dua dimensi, tiga dimensi serta media berbasis teknologi perlu dijaga mutu dan kualitasnya sehingga memberi dampak kepada proses pembelajaran. ${ }^{1}$ Penelitian lainnya juga memberikan hasil yang menyatakan bahwa media menjadi hal urgen dalam proses pembelajaran, penelitian ini dilakukan oleh Sumintono dkk. dengan menyebarkan kuisoner kepada 151 guru di Indonesia terkait penggunaan media teknologi dalam proses pembelajaran dan hasilnya bahwa guru-guru sudah mulai menggunakan media baik itu di dalam kelas maupun di laboratorium, namun masih terdapat problem dalam penggunaan media ini yaitu keterampilan atau kompetensi guru dalam mempersiapkan media tersebut. ${ }^{2}$

Media pembelajaran sudah berkembang dan beraneka, terbaru muncul media teknologi atau media digital yang digunakan dalam proses pembelajaran. Sebagaimana hasil analisa Darimi, bahwa media teknologi menjadi media yang sangat efektif untuk membantu meningkatkan kemampuan berpikir peserta didik dalam menerima pengetahuan karena dengan teknologi tersebut pembelajaran menjadi lebih menyenangkan dan dinamis. Oleh karenanya untuk mencapai pembelajaran yang efektif

\footnotetext{
${ }^{1}$ Rafiuddin Rafiuddin, M. Basri, and Muliani Azis, "Urgensi Penggunaan Media dalam Proses Pembelajaran Bagi Guru Sekolah Dasar Wilayah II Kecamatan Sanrobone Kabupaten Takalar Provinsi Sulawesi Selatan," Seminar Nasional Teknologi Pembelajaran dan Pendidikan Dasar 2017 0, no. 0 (May 4, 2017): 147-57.

${ }^{2}$ Bambang Sumintono et al., "Penggunaan Teknologi Informasi Dan Komunikasi Dalam Pengajaran : Survei Pada Guru-Guru Sains SMP Di Indonesia," Jurnal Pengajaran MIP A 17, no. 1 (January 7, 2012): 122-31, doi:10.18269/jpmipa.v17i1.251.
} 
JURNAL PIWULANG, Vol. 2 No. 2 Maret 2020, 99-111

P-ISSN : 2622-5638. E-ISSN : 2622-5654

Homepage: http://e-journal.staima-alhikam.ac.id/index.php/piwulang diperlukan dan dipersiapkan serta dirancang media berbasis teknologi informasi dan komunikasi sebagai salah satu syaratnya. ${ }^{3}$

Budiman memberikan ulasan bahwa pemilihan media yang tepat dan disesuaikan dengan karakteristik materi pelajaran seperti materi pendidikan agama Islam akan memberikan dampak positif kepada proses pembelajaran utamanya proses internalisasi nilai-nilai religius kepada peserta didik. Karena satu diantara unsur yang dapat memberikan kemudahan tercapainya tujuan pembelajaran adalah media. ${ }^{4}$ Pandangan Nurdin di dalam tulisannya menyatakan bahwa media teknologi sebagai media yang berperan sangat efektif dan efisien dalam pembelajaran pendidikan agama Islam sehingga menjadi keharusan diimplementasikan di era teknologi informasi dan komunikasi saat ini. ${ }^{5}$ karena itu pentingnya berinovasi dalam pembelajaran baik itu aspek metode maupun media sehingga memberikan banyak manfaat terutama bagi peserta didik dalam menerima dan mengembangkan pengetahuan yang mereka dapatkan di sekolah maupun madrasah.

Berdasarkan hasil penelitian dan analisis peneliti di atas, bahwasanya media menjadi penting dan urgen di dalam proses pembelajaran. Sehingga tidak dapat dipungkiri bahwa unsur media menjadi penting dikaji juga dalam konteks ajaran agama Islam, Al-Qur'an dan Hadis sebagai sumber ilmu pengetahuan memberikan banyak landasan bagi pengembangan ilmu pengetahuan itu sendiri terutama dalam aspek pendidikan yang memiliki banyak komponen seperti media pembelajaran. Berikut ayat-ayat suci al-Qur'an yang secara tersirat berkenaan dengan media pembelajaran Q.S al-Isra' (17 : 14), Q.S al-Ankabut (29 : 45), Q.S. alMuzammil (73:20), Q.S. al-Baqarah (2:31) dan Q.S an-Naml (27:29-30). Selain al-Qur'an ada juga hadis-hadis Nabi Muhammad SAW yang punya banyak nilai dan makna media pembelajaran, satu diantaranya ialah hadis riwayat Muslim berikut ini :

\footnotetext{
${ }^{3}$ Ismail Darimi, "Teknologi Informasi dan Komunikasi Sebagai Media Pembelajaran Pendidikan Agama Islam Efektif," n.d., 11.

4 Agus Budiman, "Efisiensi Metode dan Media Pembelajaran dalam Membangun Karakter

Pembelajaran Pendidikan Agama Islam,” At-Ta'dib 8, no. 1 (December 15, 2013), doi:10.21111/attadib.v8i1.514.

${ }^{5}$ Arbain Nurdin, "Inovasi Pembelajaran Pendidikan Agama Islam di Era Information and Communication Technology," TADRIS: Jurnal Pendidikan Islam 11, no. 1 (June 1, 2016): 49-64, doi:10.19105/tjpi.v11i1.971.
} 
JURNAL PIWULANG, Vol. 2 No. 2 Maret 2020, 99-111

P-ISSN : 2622-5638. E-ISSN : 2622-5654

Homepage: http://e-journal.staima-alhikam.ac.id/index.php/piwulang

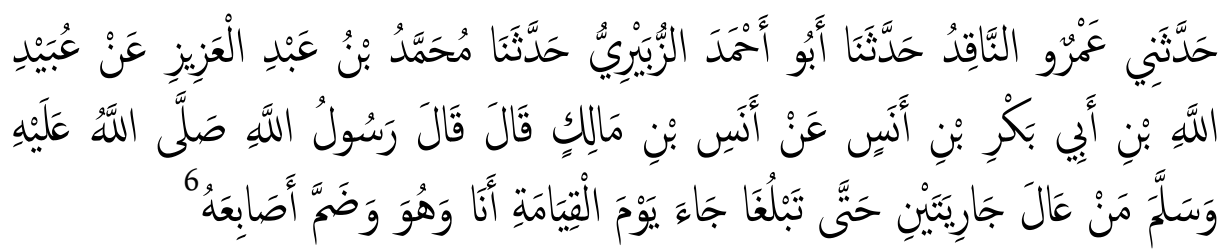

Telah menceritakan kepadaku 'Amru An Naqid; Telah menceritakan kepada kami Abu Ahmad Az Zubair; Telah menceritakan kepada kami Muhammad bin 'Abdul 'Aziz dari 'Ubaidullah bin Abu Bakr dari Anas bin Malik dia berkata; Rasulullah shallallahu 'alaihi wasallam bersabda: 'Barang siapa dapat mengasuh dua orang anak perempuannya hingga dewasa, maka aku akan bersamanya di hari kiamat kelak.' Beliau merapatkan kedua jarinya."

Berdasarkan uraian data di atas, peneliti menjadi tertarik untuk mengkaji lebih dalam terutama pada hadis riwayat Muslim tersebut yang secara teks berisi tentang pendidikan anak perempuan, oleh karena peneliti membatasi kajian ini dalam dua fokus penelitian berikut : pertama, bagaimana nilai media pembelajaran yang ada di dalam hadis riwayat Muslim bab birrun no. 149? Sedangkan fokus kedua ialah bagaimana pemahaman serta pengamalan guru praktikan dari mahasiswa prodi Ilmu Hadis Fakultas Ushuluddin IAIN Jember terhadap hadis riwayat Muslim bab birrun no. 149 ?

\section{B. PEMBAHASAN}

\section{Kajian Tarbawi}

Kata kunci di dalam hadis tersebut ialah ashaabi'u. kata ini jama' dari kata ishba'un berarti jari. Berdasarkan kamus mu'jam arab kata ashaabi'u tersebut memiliki makna sebagai berikut :

\section{Tabel 1}

\section{Makna Ashabi'u ${ }^{7}$}

\begin{tabular}{|c|c|}
\hline Asal Kata & Makna \\
\hline \multirow{2}{*}{ إِصَبَعُ ج جَأَصَابعُ } & 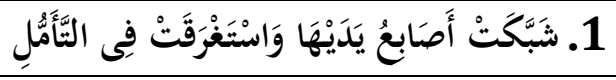 \\
\hline & 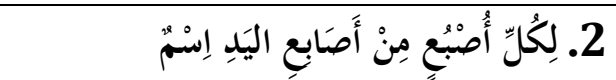 \\
\hline
\end{tabular}

6 "Shahih Muslim," n.d., http:// carihadis.com/Shahih_Muslim/4765

7 "Mu'jam al-'Arab," n.d., http:/ / ristekmuslim.com. 
Berdasarkan makna kata ashabi'u di dalam tabel tersebut, dapat diartikan secara bahasa bahwa ashabi'u memiliki makna jari jemari yang menggenggam tangannya atau jari jemari yang memiliki nama-nama tersendiri seperti jari jempol, jari telunjuk, jari tengah, jari manis dan jari kelingking. Dua makna ini menggambarkan bahwa kata ashabi'u memiliki makna secara fungsi jari jemari dan makna dilihat dari aspek jenis-jenisnya.

Pada susunan kalimat dari matan hadis tersebut menunjukkan secara umum bahwa makna ashabi'u berarti jari jemari yang digunakan oleh Nabi untuk menjelaskan atau menekankan suatu perkara yang sedang beliau sabdakan atau sampaikan kepada para sahabat yaitu tentang menjaga dua anak perempuan hingga ia dewasa kelak akan bersama Rasulullah di hari kiamat.

Menurut Gerlach dan Ely media pembelajaran mencakup tiga aspek yaitu material, equipment and technique (bahan, peralatan serta teknik). Sedangkan De Carte memaknai media yaitu segala sarana selain manusia yang memiliki tugas urgen untuk mencapai tujuan pembelajaran. Selain itu, makna media juga dapat diartikan secara luas yaitu setiap insan dan materi atau bahan yang memberikan kesempatan kepada peserta didik untuk mendapatkan pengetahuan. Pemaknaan ini dapat diterima bila media yang digunakan tidak sebatas alat atau materi atau bahan yang sudah dirancang sedemikian rupa oleh manusia dalam hal ini pendidik atau guru. Namun ada juga pendapat lain yang menyatakan media hanya sebatas alat atau bahan dan materi. Pendapat ini dapat dilihat seperti pandangan Rossi dan Breidle yang memaknai media sebatas alat seperti radio, televisi, buku, Koran dan sebagainya. ${ }^{8}$

Pemaknaan media pembelajaran yang disampaikan di atas dapat dibagi menjadi dua makna media yaitu makna media secara luas setiap insan dan materi, sedangkan makna media secara sempit diarikan hanya sebatas alat. Dan tujuan media semuanya sama untuk memudahkan peserta didik menerima pengetahuan dari para pendidik. Oleh karenanya, bila makna media diartikan secara sempit maka klasifikasi media pun hanya sebatas alat saja seperti pandangan Gerlach dan Ely

${ }^{8}$ Arbain Nurdin, Pembelajaran Qur'an Hadis Di Madrasah (Bantul: Ladang Kata, 2018). 
JURNAL PIWULANG, Vol. 2 No. 2 Maret 2020, 99-111

P-ISSN : 2622-5638. E-ISSN : 2622-5654

Homepage: http://e-journal.staima-alhikam.ac.id/index.php/piwulang

berikut ini "The term instructional media includes a wide range of material, equipment and technique; chalkboard, bulletin board, filmstrips, slides, motion pictures, television, programmed instruction, models, demonstrations, charts, maps, books, and combination of these"

Adapun pemaknaan media diarikan lebih luas, maka akan berdampak kepada klasifikasi media itu sendiri seperti pandangan yang disampaikan oleh Ramli bahwa media dapat dibagi menjadi ada bagian : pertama media dalam konteks perilaku atau bisa disebut dengan media dari perilaku guru atau pendidik. Kedua, media dalam konteks benda yang biasa disebut dengan media yang tampak secara kasat mata. ${ }^{10}$

Manfaat media dalam pembelajaran dapat memberikan banyak kemudahan, Kemp dan Dayton menjelaskan bahwa ada delapan manfaat media dalam proses pembelajaran sebagai berikut:

a. Materi pelajaran dapat dijelaskan bersamaan;

b. Pembelajaran di kelas tidak membosankan;

c. Terjadinya interaksi antara guru dan peserta didik di dalam pembelajaran;

d. Media dapat memberikan waktu penjelasan materi lebih efektif;

e. Mutu dan hasil belajar siswa dapat meningkat;

f. Media dapat memberikan waktu pembelajaran lebih dinamis;

g. Media berdampak positif bagi tumbuhnya minat siswa terhadap materi pelajaran;

h. Tugas dan posisi guru menjadi lebih produktif.11

Berdasarkan pemaknaan kata kunci dan teori tentang media pembelajaran dapat dipahami bahwa media pembelajaran yang digunakan oleh Nabi di dalam hadis tersebut dapat dikategorikan ke dalam jenis media pembelajaran berupa konteks perilaku atau perbuatan yang menggunakan jari jemari sebagai media atau alat penyampai pesan informasi (matan hadis) tentang apa yang ingin diajarkan kepada para sahabat di kala itu. Oleh karenanya, jari jemari

\footnotetext{
${ }^{9}$ Ibid.

${ }^{10}$ Abdul Haris Pito, "Media Pembelajaran Dalam Perspektif Al-Qur'an," Andragogi: Jurnal Diklat Teknis Pendidikan Dan Keagamaan 6, no. 2 (December 31, 2018): 97-117, doi:10.36052/andragogi.v6i2.59.

${ }^{11}$ Isran Rasyid Karo-Karo and Rohani Rohani, "Manfaat Media Dalam Pembelajaran," AXIOM : Jurnal Pendidikan Dan Matematika 7, no. 1 (June 29, 2018), http://jurnal.uinsu.ac.id/index.php/axiom/article/view/1778.
} 
JURNAL PIWULANG, Vol. 2 No. 2 Maret 2020, 99-111

P-ISSN : 2622-5638. E-ISSN : 2622-5654

Homepage: http://e-journal.staima-alhikam.ac.id/index.php/piwulang

yang digunakan Nabi dapat memberi manfaat sebagaimana manfaat media diantaranya ialah adanya kemudahan interaksi antara guru (Nabi) dan peserta didik (sahabat).

\section{Kajian Living Hadis}

Secara teoritis, living hadis atau living sunnah menurut Mansyur dkk. adalah gaya penafsiran atau bisa disebut hasil ijtihad masyarakat atau komunitas tertentu terhadap matan sebuah hadis yang mereka baca sehari-hari, gaya ini pastinya berbeda-beda antar masyarakat tergantung keilmuan yang mereka peroleh, sehingga ketika mereka menafsirkan dan memahami sebuah matan hadis, mereka. menyepakati amaliyahnya bersama-sama sesuai tingkat pemahaman mereka. Sedangkan Sumbulah memaknai living hadis dari aspek penelitian dan kajian sosial yang terjadi di tengah-tengah masyarakat berkenaan dengan teks hadis yang mereka pahami dan amalkan dalam komunitas itu sendiri maupun bersama masyakarat lainnya. ${ }^{12}$

Berdasarkan makna living hadis di atas dapat diartikan bahwa living hadis merupakan gaya penafsiran masyarakat yang membaca teks hadis lalu mempraktikkannya dalam konteks dan ruang lingkup masyarakat itu sendiri. Living hadis dapat diklasifikasin ke dalam tiga aspek yaitu tradisi tulis yaitu tradisi yang konsisten dilaksanakan oleh masyarakat atau komunitas dalam rangka menghidupkan tulisan-tulisan bernuansa agamis yang bersumber dari hadis Nabi seperti athahuru syathru al-iman yang dipajang di dinding sekolah atau tempat titik kumpul masyarakat. Tradisi lisan ialah tradisi mengucapkan sebuah lafadz baik seperti kalimat asma'ul husna atau lafadz-lafadz dzikir, shalawat dalam kehidupan sehari-hari dan dilakukan secara bersamasama maupun sendiri, dan tradisi praktik. Ketiga tradisi ini sesuai dengan tingkat keilmuan yang masyarakat miliki untuk mempraktikkannya.

Sebagai contoh tradisi praktik yang dilakukan oleh mahasiswa Perguruan Tinggi Negeri (PTN) di kabupaten Jember yaitu tradisi malam nisyfhu Sya'ban. Tradisi ini bisa berupa amalan-amalan yang mereka fahami dan tafsiri dari teks sebuah hadis yang mereka pelajari waktu di

12 Arbain Nurdin and Ahmad Fajar Shodik, Studi Hadis : Teori \& Aplikasi (Bantul: Ladang Kata, 2019). 
JURNAL PIWULANG, Vol. 2 No. 2 Maret 2020, 99-111

P-ISSN : 2622-5638. E-ISSN : 2622-5654

Homepage: http://e-journal.staima-alhikam.ac.id/index.php/piwulang

sekolah maupun madrasah. Selain itu mereka juga mendapatkan pengetahuan tentang amalan-amalan tersebut dari berbagai sumber seperti ustadz, dari group media sosial dan lainnya, walaupun secara kualitas hadis mereka belum mengetahuinya. Dan tradisi amalan malam nisyfhu sya'ban ini tetap eksis dan berjalan di kalangan mahasiswa PTN kabupaten Jember. ${ }^{13}$

Pada penelitian ini fokusnya kepada tradisi praktik, hal ini disesuaikan pemahaman peneliti yang memaknai teks hadis riwayat muslim ini menceritakan bagaimana Rasulullah menyampaikan materi/matan hadis dan menjelaskannya dengan menggunakan jari jemarinya. Pemaknaan jari jemari ini, peneliti maknai sebagai media dalam menyampaikan sebuah materi bila dikaitkan dengan pendidikan maupun pembelajaran di lembaga formal maka makna jari jemari bisa diartikan sebagai media pembelajaran.

Fokus kedua ini bertujuan mendeskripsikan pemahaman serta pengamalan guru praktikan dari mahasiswa prodi ilmu hadis fakultas ushuluddin IAIN Jember terhadap hadis riwayat Muslim bab birrun no. 149. Ada beberapa alasan peneliti memilih informan dari kalangan mahasiswa prodi ilmu hadis yang sedang atau sudah melakukan praktik pengalaman lapangan/magang di sekolah maupun madrasah-madrasah ialah :

a. Memiliki kompetensi ilmu hadis secara teoritis;

b. Memiliki pengalaman menempuh program praktik pengalaman lapangan tentang ilmu kependidikan selama satu semester.

Langkah-langkah living hadis yang peneliti lakukan sebagaimana pandangan Sumbulah sebagai berikut : a) melakukan observasi terlebih dahulu kepada masyarakat yang telah mentradisikan pemahaman mereka terhadap sebuah hadis, lalu hadis tersebut dipilih untuk diteliti lebih detail lagi baik secara sanad, matan atau maknanya; b) mencari dan menentukan informan/responden; c) teknik pengumpulan data bisa berupa wawancara, observasi dan dokumentasi; d) instrumen penelitian dibuat untuk membantu peneliti memetakan jawaban informan; e)

\footnotetext{
13 Arbain Nurdin, “Tradisi Menghidupkan Malam Nishfu Sya’ban Pada Kalangan Mahasiswa Di Kabupaten Jember (Studi Kritik Sanad, Matan Dan Living Sunnah)," Al-Banjari : Jurnal Ilmiah Ilmu-Ilmu Keislaman 16, no. 2 (November 15, 2017): 203-34, doi:10.18592/al-banjari.v16i2.1470.
} 
JURNAL PIWULANG, Vol. 2 No. 2 Maret 2020, 99-111

P-ISSN : 2622-5638. E-ISSN : 2622-5654

Homepage: http://e-journal.staima-alhikam.ac.id/index.php/piwulang

memulai penelitian dengan berbagai teknik pengumpulan data yang sudah ditentukan sebelumnya; f) menganalisis setiap data yang diperoleh dari informan; g) mengecek keabsahan data dengan berbagai teknik; h) membuat serta menyusun laporan hasil penelitian. ${ }^{14}$

Langkah pertama ini peneliti lakukan saat memberi perkulihan kepada mahasiswa prodi ilmu hadis yang mengampu mata kuliah pembelajaran al-Qur'an Hadis, pada saat sesi praktik atau microteaching para mahasiswa mempraktikkan bagaimana menggunakan media dalam proses pembelajaran baik itu dalam konteks media prilaku maupun benda seperti visual, audio ataupun multimedia. Dan proses ini berlansung kurang lebih satu semester atau 14 kali tatap muka. Langkah kedua, berdasarkan hasil pengamatan di dalam proses perkuliahan microteaching tersebut, peneliti memilih dan menentukan informan living hadis ini semuanya berasal dari mahasiswa yang mengampu mata kuliah tersebut.

Langkah ketiga, peneliti memilih teknik wawancara sebagai teknik pengumpulan data, dan instrumen dari teknik ini ialah pertanyaanpertanyaan yang mengarah kepada dua aspek yaitu pengetahuan tentang media pembelajaran serta pemahaman tentang makna hadis dan pengamalannya dalam praktik pembelajaran lapangan yang sedang mereka ikuti. Hasil dari living hadis yang menjadi langkah-langkah selanjutnya mulai dari analisa data, menkonfirmasi data dengan teknik keabsahan data berupa diskusi teman sejawat lalu hasilnya disimpulkan sebagai berikut :

Informan A menyatakan bahwa media pembelajaran yang ia pahami sebagai sebuah alat ataupun bahan yang dapat meningkatkan mutu pembelajaran, artinya dengan adanya media guru dapat meningkatkan kualitas mengajarnya. 15 informan B memberikan tanggapan berbeda, ia menyatakan bahwa media pembelajaran ialah alat yang dapat melihat sejauh mana efektifitas dan kreativitas seorang guru dalam proses pembelajaran berlangsung. ${ }^{16}$ Kedua informan ini memahami sebuah media berdasarkan tujuan dan manfaatnya, bila informan A mengatakan media memberi manfaat untuk meningkatkan

\footnotetext{
${ }^{14}$ Nurdin and Shodik, Studi Hadis : Teori \& Aplikasi.

15 Fadilatus Sahriyati, Wawancara, February 5, 2020.

16 Abdul Haris, Wawancara, February 6, 2020.
} 
JURNAL PIWULANG, Vol. 2 No. 2 Maret 2020, 99-111

P-ISSN : 2622-5638. E-ISSN : 2622-5654

Homepage: http://e-journal.staima-alhikam.ac.id/index.php/piwulang

mutu mengajar seorang guru sedangkan informan B menyatakan bahwa media memberi manfaat untuk meningkatkan efektifitas dan kreatifitas guru dalam proses pembelajaran.

Tanggapan lain berasal dari informan $\mathrm{C}$ yang menyatakan bahwa media pembelajaran yang ia pahami adalah sebuah alat yang dapat menyampaikan materi kepada peserta didik. ${ }^{17}$ sedangkan informan D memberikan tanggapan bahwa media sebagai alat yang memberi kemudahan bagi seorang guru untuk menyampaikan semua materi pelajaran. ${ }^{18}$ Jawaban dari kedua informan ini memberikan makna bahwa media pembelajaran yang mereka fahami adalah alat yang membantu guru dan tenaga pendidik lainnya dalam menyampaikan materi pelajaran. Artinya, media adalah alat bantu dan menjadi sebuah kebutuhan bagi seorang guru untuk digunakan dalam proses pembelajaran.

Pada aspek pemahaman hadis riwayat Muslim ini, para informan memberikan tanggapan yang berbeda-beda sebagai berikut : informan A memahaminya sebagai kunci sukses kedua orang tua kelak di hari kiamat ialah tatkala mampu mendidik kedua putrinya dengan pendidikan yang sebenar-benarnya. ${ }^{19}$ Sedangkan informan B memahaminya sebatas tugas kedua orang tua hanyalah menjadikan putrinya menjadi sholehah. ${ }^{20}$ Informan $\mathrm{C}$ menanggapinya sebagai hadis yang mengajarkan kepada kita bahwa menjaga anak perempuan lebih sulit dibandingkan menjaga anak laki-laki. ${ }^{21}$ Selanjutnya informan D memberi jawaban bahwa hadis ini dapat dipahami sebagai petunjuk bagi kita selaku umat Islam bahwa Rasulullah menyuruh umatnya untuk menjaga dan memilihara anak perempuannya dengan penjagaan dan pemeliharaan yang baik, sembari menekankan maksud penjagaan dan pemeliharaan tersebut dengan menggunakan jari jemari beliau. ${ }^{22}$

Jawaban para informan tentang makna hadis tersebut dapat disimpulkan bahwa mereka memahami teks atau matan hadis tersebut sesuai dengan teksnya atau bersifat tekstual, namun informan D

${ }^{17}$ Umi Latifatub Nihayah, Wawancara, February 7, 2020.

18 Sony Alba Firdaus, Wawancara, February 8, 2020.

${ }^{19}$ Sahriyati, Wawancara.

${ }^{20}$ Haris, Wawancara.

${ }^{21}$ Nihayah, Wawancara.

22 Firdaus, Wawancara. 
JURNAL PIWULANG, Vol. 2 No. 2 Maret 2020, 99-111

P-ISSN : 2622-5638. E-ISSN : 2622-5654

Homepage: http://e-journal.staima-alhikam.ac.id/index.php/piwulang

memahami sedikit lebih kepada kontekstual walaupun tanpa menyebutkan istilah media atau alat dalam jawabannya, hanya memberi penekanan maksud kata jaga dan pelihara dengan menggunakan jari jemari Rasulullah.

Aspek tradisi atau mentradisikan penggunaan jari jemari sebagai media dalam proses pembelajaran juga ditanggapi beragam oleh informan, jawaban mereka sebagai berikut : informan A menyatakan bahwa ia sering menggunakan jari jemari sebagai media atau alat penyampai dan penjelas materi pelajaran. ${ }^{23}$ Informan B sebaliknya tidak menggunakan jari jemari walaupun ia menyatakan bahwa Rasulullah di dalam hadis tersebut menjelaskan maksud atau makna hadis dengan jari jemarinya. ${ }^{24}$ Informan C mengiyakan bahwa selalu menggunakan jari jemari untuk menjelaskan materi pelajaran. ${ }^{25}$ Informan D menanggapi kadang menggunakan kadang tidak tergantung jenis materi pelajarannya. ${ }^{26}$ Berdasarkan jawaban informan tersebut bahwa mereka sering dan kadang menggunakan jari jemari sebagai media dalam proses pembelajaran, sehingga hadis tersebut mereka pahami dan tradisikan dalam proses pembelajaran walaupun sebatas media pembelajaran saja.

\section{KESIMPULAN}

Berdasarkan pembahasan dan analisa data penelitian di atas, maka dapat disimpulkan sebagai berikut:

1. Hadis riwayat Muslim bab birrun no. 149 ini dapat diartikan sebagai hadis tentang media pembelajaran. Hal ini sesuai dengan kajian serta analisa tarbawi ditemukan aspek atau nilai pendidikan berupa media pembelajaran di dalam sususan kalimat hadis tersebut dengan kata kunci ashobi'u yang berarti jari jemari, dan makna ini dapat kategorikan dalam jenis media prilaku bukan media benda.

2. Hasil kajian living hadis riwayat Muslim bab birrun no. 149 ini didapatkan bahwa hampir semua informan mengetahui dan memahami maksud hadis tersebut, dan mereka juga mentradisikan media

${ }^{23}$ Sahriyati, Wawancara.

${ }^{24}$ Haris, Wawancara.

${ }^{25}$ Nihayah, Wawancara.

${ }^{26}$ Firdaus, Wawancara. 
JURNAL PIWULANG, Vol. 2 No. 2 Maret 2020, 99-111

P-ISSN : 2622-5638. E-ISSN : 2622-5654

Homepage: http://e-journal.staima-alhikam.ac.id/index.php/piwulang

tangan/jari jemari sebagai alat atau petunjuk materi dalam proses pembelajaran.

\section{DAFTAR PUSTAKA}

Budiman, Agus. "Efisiensi Metode dan Media Pembelajaran dalam Membangun Karakter Pembelajaran Pendidikan Agama Islam.” At-Ta'dib 8, no. 1 (December 15, 2013). doi:10.21111/at-tadib.v8i1.514.

Darimi, Ismail. "Teknologi Informasi dan Komunikasi Sebagai Media Pembelajaran Pendidikan Agama Islam Efektif," n.d., 11.

Firdaus, Sony Alba. Wawancara, February 8, 2020.

Haris, Abdul. Wawancara, February 6, 2020.

Karo-Karo, Isran Rasyid, and Rohani Rohani. "Manfaat Media Dalam Pembelajaran." AXIOM : Jurnal Pendidikan Dan Matematika 7, no. 1 (June 29, 2018). http://jurnal.uinsu.ac.id/index.php/axiom/article/view/1778.

“Mu'jam al-'Arab," n.d. http://ristekmuslim.com.

Nihayah, Umi Latifatub. Wawancara, February 7, 2020.

Nurdin, Arbain. "Inovasi Pembelajaran Pendidikan Agama Islam di Era Information and Communication Technology." TADRIS: Jurnal Pendidikan Islam 11, no. 1 (June 1, 2016): 49-64. doi:10.19105/tjpi.v11i1.971.

___. Pembelajaran Qur'an Hadis Di Madrasah. Bantul: Ladang Kata, 2018.

- - C. “Tradisi Menghidupkan Malam Nishfu Sya'ban Pada Kalangan Mahasiswa Di Kabupaten Jember (Studi Kritik Sanad, Matan Dan Living Sunnah)." Al-Banjari: Jurnal Ilmiah Ilmu-Ilmu Keislaman 16, no. 2 (November 15, 2017): 203-34. doi:10.18592/al-banjari.v16i2.1470.

Nurdin, Arbain, and Ahmad Fajar Shodik. Studi Hadis : Teori \& Aplikasi. Bantul: Ladang Kata, 2019.

Pito, Abdul Haris. "Media Pembelajaran Dalam Perspektif Al-Qur'an." Andragogi: Jurnal Diklat Teknis Pendidikan Dan Keagamaan 6, no. 2 (December 31, 2018): 97-117. doi:10.36052/andragogi.v6i2.59. 
JURNAL PIWULANG, Vol. 2 No. 2 Maret 2020, 99-111

P-ISSN : 2622-5638. E-ISSN : 2622-5654

Homepage: http://e-journal.staima-alhikam.ac.id/index.php/piwulang

Rafiuddin, Rafiuddin, M. Basri, and Muliani Azis. "Urgensi Penggunaan Media dalam Proses Pembelajaran Bagi Guru Sekolah Dasar Wilayah II Kecamatan Sanrobone Kabupaten Takalar Provinsi Sulawesi Selatan." Seminar Nasional Teknologi Pembelajaran dan Pendidikan Dasar 2017 0, no. 0 (May 4, 2017): 147-57.

Sahriyati, Fadilatus. Wawancara, February 5, 2020.

"Shahih Muslim," n.d. http://carihadis.com/Shahih_Muslim/4765.

Sumintono, Bambang, Setiawan Agung Wibowo, Nora Mislan, and Dayang Hjh Tiawa. "Penggunaan Teknologi Informasi Dan Komunikasi Dalam Pengajaran: Survei Pada Guru-Guru Sains SMP Di Indonesia." Jurnal Pengajaran MIPA 17, no. 1 (January 7, 2012): 122-31. doi:10.18269/jpmipa.v17i1.251. 